\title{
Strength and deformability of hollow concrete blocks: correlation of block and cylindrical sample test results
}

\section{Resistência e deformabilidade de blocos vazados de concreto: correlação entre os resultados experimentais de blocos e corpos-de-prova cilíndricos}
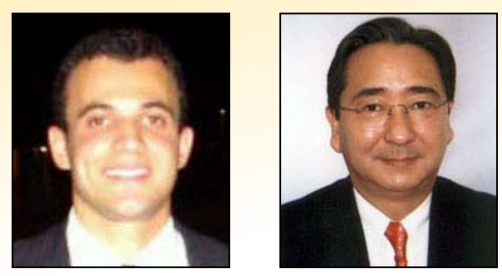

C. S. BARBOSA

claudiusbarbosa@yahoo.com.br

J.B. HANAI ${ }^{b}$

jbhanai@sc.usp.br

\begin{abstract}
This paper deals with correlations among mechanical properties of hollow blocks and those of concrete used to make them. Concrete hollow blocks and test samples were moulded with plastic consistency concrete, to assure the same material in all cases, in three different levels of strength (nominally $10 \mathrm{~N} / \mathrm{mm}^{2}, 20 \mathrm{~N} / \mathrm{mm}^{2}$ and $30 \mathrm{~N} / \mathrm{mm}^{2}$ ). The mechanical properties and structural behaviour in axial compression and tension tests were determined by standard tests in blocks and cylinders. Stress and strain analyses were made based on concrete's modulus of elasticity obtained in the sample tests as well as on measured strain in the blocks' face-shells and webs. A peculiar stress-strain analysis, based on the superposition of effects, provided an estimation of the block load capacity based on its deformations. In addition, a tentative method to preview the block deformability from the concrete mechanical properties is described and tested. This analysis is a part of a broader research that aims to support a detailed structural analysis of blocks, prisms and masonry constructions.
\end{abstract}

Keywords: structural masonry, concrete block, mechanical properties, strength, deformability.

\section{Resumo}

Este trabalho trata das correlações entre as propriedades mecânicas de blocos vazados e do concreto que o constitui. Foram moldados blocos vazados e corpos-de-prova com concreto de consistência plástica para que fosse garantido o mesmo material em todos os casos, para três diferentes níveis de resistência $\left(10 \mathrm{~N} / \mathrm{mm}^{2}, 20 \mathrm{~N} / \mathrm{mm}^{2}\right.$ e $\left.30 \mathrm{~N} / \mathrm{mm}^{2}\right)$. As propriedades mecânicas e o comportamento estrutural sob compressão axial e tração foram obtidos por meio de ensaios padronizados com blocos e corpos-de-prova. Uma análise de tensões e deformações foi realizada com base no módulo de elasticidade do concreto obtido no ensaio com corpo-de-prova e também por meio da medição da deformação nas paredes longitudinais e septos transversais dos blocos. Uma análise peculiar sobre a relação tensão-deformação, baseada na superposição dos efeitos, permitiu a previsão da capacidade de carga do bloco a partir dos valores de suas deformações. Além disso, um método de previsão da deformabilidade do bloco a partir das propriedades mecânicas do concreto e descrito e avaliado. Este estudo é parte de uma pesquisa mais ampla que objetiva estudar detalhadamente do comportamento estrutural de blocos, prismas e paredes.

Palavras-chave: alvenaria estrutural, bloco de concreto, propriedades mechanicas, resistência, deformabilidade.

\footnotetext{
Ph.D. Student, School of Engineering at Sao Carlos, Department of Structural Engineering, University of Sao Paulo, claudiusbarbosa@yahoo.com.br . Av. do Trabalhador Sao Carlense, 400, 13566-590 Sao Carlos, Brazil.

b Professor, School of Engineering at Sao Carlos, Department of Structural Engineering, University of Sao Paulo, jbhanai@sc.usp.br Av. do Trabalhador Sao Carlense, 400, 13566-590 Sao Carlos, Brazil.
} 


\section{Introduction}

Despite of the scientific evolution of structural masonry technology in recent years, the design methods and structural safety analyses still need hard improvements.

The current knowledge does not clearly establish an accurate group of strength and deformation parameters and their respective weighting and safety factors for a Limit State analysis. It is necessary to go forward detailing factors that are related to material's properties, unit production methods, construction procedures and quality control. The application of the Limit States concept or other improved probabilistic methods demands a better knowledge of each parameter that influences the structural behaviour at service and ultimate stages. There are many challenges to be succeeded, especially because many of these parameters are derived from tests where the conditions are not unique. Block geometry is different from case to case, concrete mechanical properties inside the units are not perfectly characterized, confinement effects in block and prism tests are variable, steel plate stiffness affects the stress distribution in the tests, behaviour of bedding mortar involves complex phenomena, etc. Some research projects (see Gomes [1], Berto et al. [2], Drobiec [3] and Köksal et al. [4]) have been working on numerical models for masonry structures, such as micromodelling (which details 3D blocks) of masonry elements. Nevertheless, the theoretical methods usually assume constitutive equations or mechanical properties obtained from standardized tests of concrete samples. This assumption does not correspond to reality, because both concrete block and bedding mortar are moulded and cured in different conditions. Several researchers have tried to determine the mechanical properties of concrete inside the block by extracting samples from them. However, this is not an easy method and some uncertainties may appear due to the small dimensions of the samples.

This paper reports a tentative analysis to correlate the mechanical behavior of cylindrical concrete samples to the structural behavior of hollow concrete blocks. Instead of analyzing blocks with unknown concrete properties, plastic consistency concrete was used to mould hollow blocks and test samples to assure the same material's properties. Three concrete strength levels were defined to simulate distinct deformability conditions.

The further steps of the ongoing research are the performance of new test series and the calibration of theoretical models for direct and reverse analyses.

Many factors affect the compressive strength test results of masonry units, especially the confinement effect that significantly changes the strength of the similar elements. Hendry [5] compares test results of bricks and blocks made of the same material and tested under the same conditions. Different strength values were observed since bricks have a more favourable geometric configuration looking at the platen effect in the test. This justifies the direct influence of the external dimensions on the behaviour of the unit. The restriction caused by the test platens enables transversal confinement stresses that introduce a triaxial stress state to the block

Table 1 - Researches that correlate the compressive strength of block and samples

\begin{tabular}{|c|c|c|c|c|}
\hline Author & Sample & Proportions & Block & Relationship \\
\hline $\begin{array}{l}\text { Becica and Harris } \\
\text { (9) }\end{array}$ & $\begin{array}{l}\text { Prismatic, } \\
\text { extracted from } \\
\text { block }\end{array}$ & $\begin{array}{c}1: 1 \text { to } 1: 2 \\
\text { (height:width) }\end{array}$ & $\begin{array}{c}\text { Hollow } \\
(200 \times 200 \times 390 \mathrm{~mm})\end{array}$ & 1,22 \\
\hline $\begin{array}{l}\text { Frasson Junior } \\
\text { (12) }\end{array}$ & $\begin{array}{l}\text { Moulded with } \\
\text { zero-slump } \\
\text { concrete }\end{array}$ & $50 \times 100 \mathrm{~mm}$ & $\begin{array}{c}\text { Hollow } \\
(140 \times 190 \times 390 \mathrm{~mm})\end{array}$ & 0,80 \\
\hline $\begin{array}{l}\text { Ganzerli et al. } \\
\text { (11) }\end{array}$ & $\begin{array}{c}\text { Prismatic, } \\
\text { extracted from } \\
\text { block top } \\
\text { Prismatic, } \\
\text { extracted from } \\
\text { block bottom }\end{array}$ & $\begin{array}{c}1: 2: 4 \\
\text { (height: } \\
\text { width:length) }\end{array}$ & $\begin{array}{c}\text { Hollow } \\
(200 \times 200 \times 390 \mathrm{~mm})\end{array}$ & $\begin{array}{l}1,41 \\
1,12\end{array}$ \\
\hline Marzahn (6) & $\begin{array}{l}\text { Cylindrical, } \\
\text { extract from } \\
\text { block }\end{array}$ & $100 \times 200 \mathrm{~mm}$ & $\begin{array}{c}\text { Solid calcium } \\
\text { silicate } \\
(238 \times 240 \times 500 \mathrm{~mm}) \\
\text { Solid concrete } \\
(200 \times 240 \times 500 \mathrm{~mm})\end{array}$ & $\begin{array}{l}0,61-0,66 \\
0,86-0,95\end{array}$ \\
\hline
\end{tabular}


and, consequently, a higher compressive strength. Therefore, the compressive strength is related to block geometric characteristics, as the aspect ratio - relationship between the height and thickness of the element. This means that increasing the block height and keeping the other dimensions constant, smaller compressive strength is to be expected.

Compressive strength is, obviously, the most important masonry parameter, as compression forces are the main actions in this kind of structure. However, knowledge of tensile strength of blocks is important, since the main structural limitations in masonry construction are due to tensile stresses.

Tests with three elements - blocks, prisms and walls - usually define the compressive strength of the masonry walls. However, structural behaviour of prisms and walls is very different from the observed in isolated unit tests. Slenderness of prisms and walls and the presence of mortar joints change the failure mode and the average strength. Therefore, the mechanical properties of masonry are directly referred to the tested element (block, prism or wall), and not to the properties of the constituent materials (concrete and mortar).

Marzahn [6] relates that it is necessary a much accurate analysis of masonry structural behaviour especially because the mechanical properties (as found by the standard test method) are not adequate to represent the condition in a numerical micromodelling for masonry computational simulation or failure conditions. In accordance to Pina-Henriques [7], in a numerical micromodelling it is meaningful to have a closer evaluation of mechanical properties of masonry constituent materials, e.g., concrete and bedding mortar. Many re- searchers followed this reasoning, like Hamid and Chukwunenye [8] that performed numerical simulations on prisms in which the block modulus of elasticity was obtained by tests in samples extracted from the concrete blocks tested by Becica and Harris [9]. Also Hawk et al. [10] and Ganzerli et al. [11] tested samples extracted from hollow concrete blocks. Marzahn [6] extracted cylindrical samples from solid calcium silicate and concrete from which compressive and tensile strength and modulus of elasticity were obtained.

Frasson Junior [12] tested cylindrical samples $(50 \times 100 \mathrm{~mm})$ constituted by zero-slump concrete used to manufacture hollow concrete blocks. The compressive strength of moulded samples was lower than from blocks, referring to the net area, but no detailed analysis of results was made.

Many difficulties are found in researches that aim to characterize the mechanical properties of constituent material of masonry unit, mainly because concrete blocks have a distinct moulding process in comparison to moulding test samples. Therefore, some researches utilize samples extracted from units, assuring equality of material mechanical properties. However, the extraction process is a difficult method that demands care, cost and time; besides, it may damage the extracted samples.

Becica and Harris [9] and Ganzerli et al. [11] obtained compressive strength values in concrete sample tests about $24 \%$ higher than in block tests. Frasson Junior [12] found these values $20 \%$ lower than in block tests. In Marzahn [6] tests, the values of concrete strength varied from $60 \%$ to $95 \%$ of block strength, depending on the type of block. Each one of the discussed works has its particularities.

\section{Figure 1 - Hollow concrete block geometry (in centimeters) (a). Steel mold and EPS units to provide cores (b)}

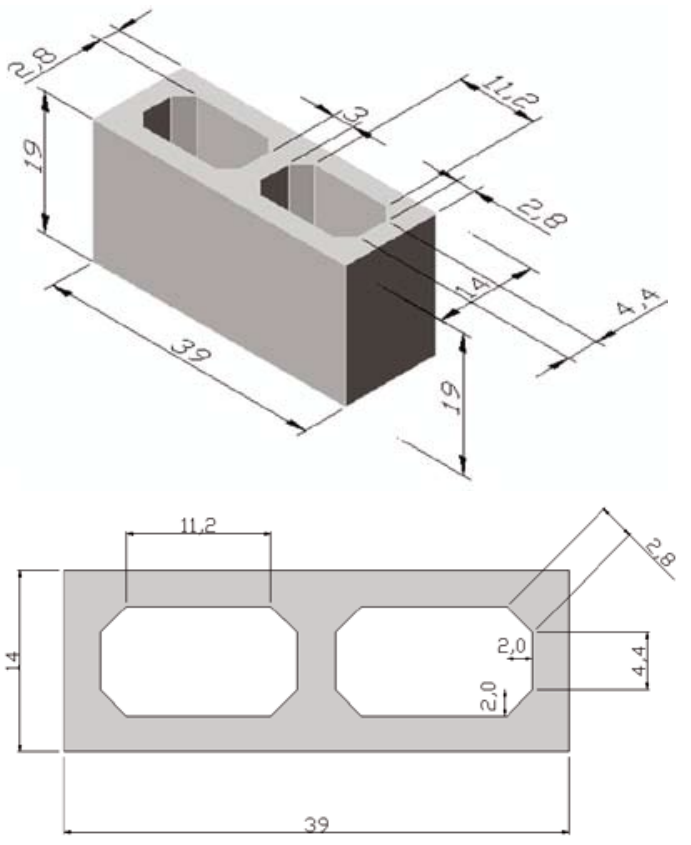

(a)

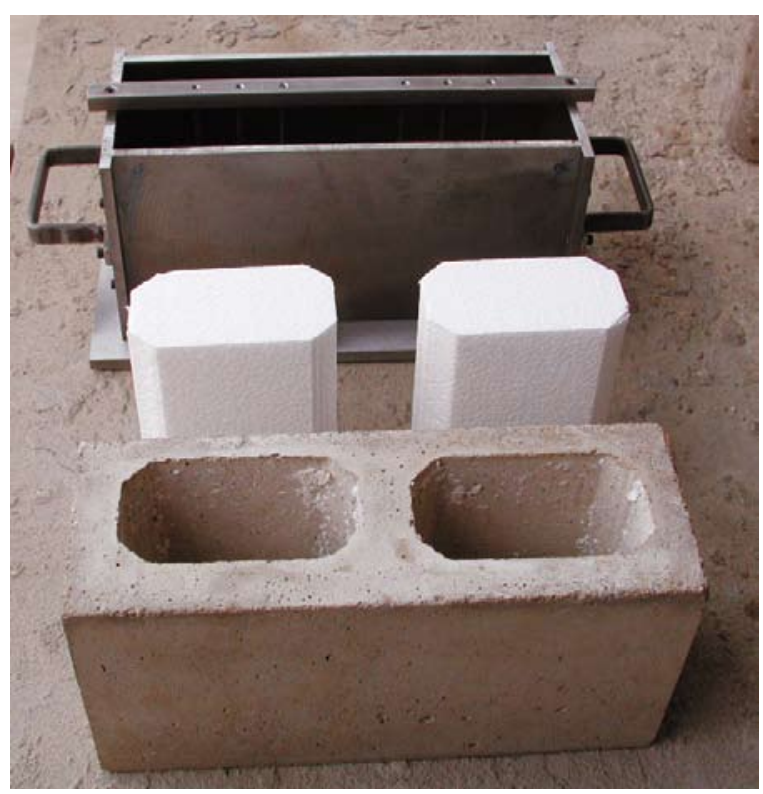

(b) 


\section{Figure 2 - Casting and vibration of blocks (a) and (b). Elements flattened with a thin sulphur layer (c)}

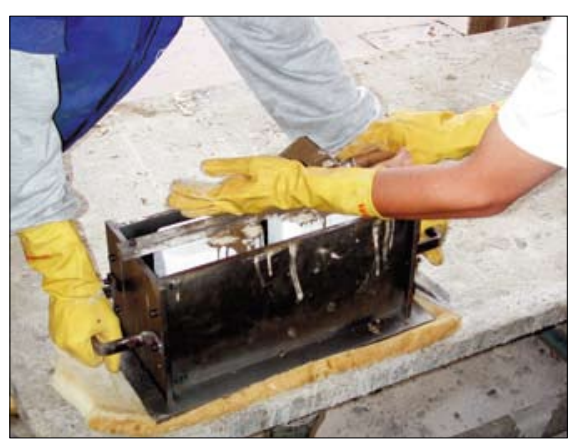

(a)

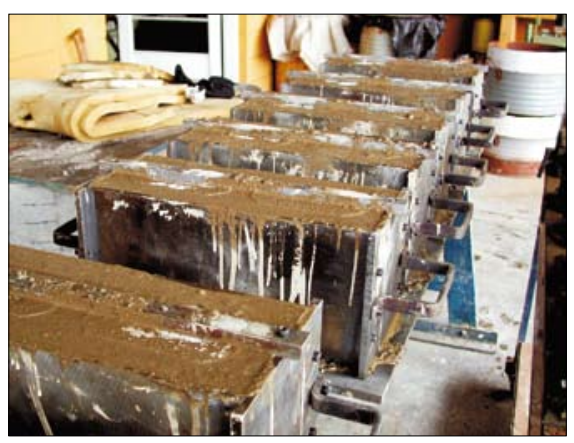

(b)

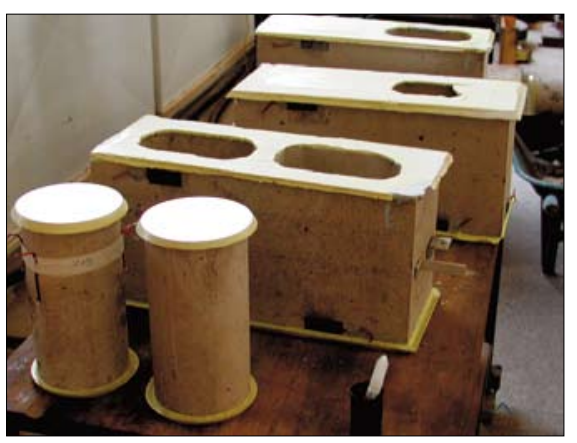

(c)
Prismatic and cylindrical samples with different dimensions and preparation method (moulded or extracted) were tested. Barbosa [13] reports a more detailed description of these tests.

Correlations between the compressive strength of blocks and samples found in the researches described above are summarized in Table 1. As steel platen restraint and unit geometry cause significant effects on test results, a summary of previous researches is presented. In these analyses, a better standardization of samples is important due to the influence of platen restraint and sample geometry on test results. Thus, it is necessary to define a sample that represent the behaviour of the block under axial compression.

\section{Experimental program}

Hollow concrete blocks and cylindrical samples with plastic consistency concrete were moulded in three nominal levels of com- pressive strength: $10 \mathrm{~N} / \mathrm{mm}^{2}, 20 \mathrm{~N} / \mathrm{mm}^{2}$ and $30 \mathrm{~N} / \mathrm{mm}^{2}$. Concrete blocks and samples were cast according to the same steps: concrete placement, vibration, cure, demoulding and finishing (top and bottom flattening with a thin sulphur layer).

Steel moulds were used to prepare concrete blocks. Internal cores were provided by two EPS (expanded polystyrene) blocks fixed to the steel mould, as illustrated in Figure 1. The EPS units were extracted right after 7 days.

All the blocks were manufactured in laboratory to assure the desired concrete strength, high process quality and geometric precision. Some of these steps are illustrated in Figure 2.

Concrete blocks and cylindrical samples were subjected to axial compression force in a servo-hydraulic machine and tested in linearly controlled displacement mode. The controlled displacement mode allowed acquisition of stress-strain graphs, including the softening branch.

\section{Figure 3 - Loading and data acquisition system (a). Scheme of block test (b)}

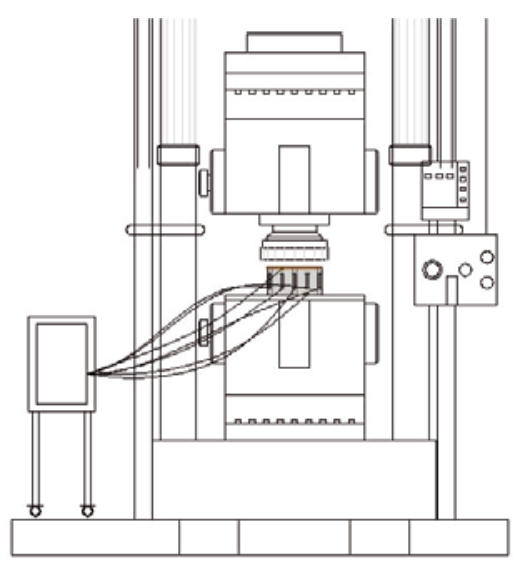

(a)

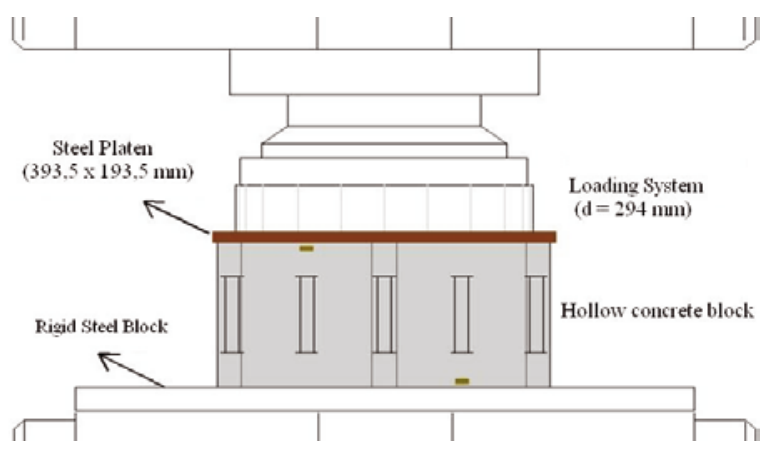

(b) 


\section{Figure 4 - Location of displacement transducers in a block (a) and in a cylinder (b)}

(3)

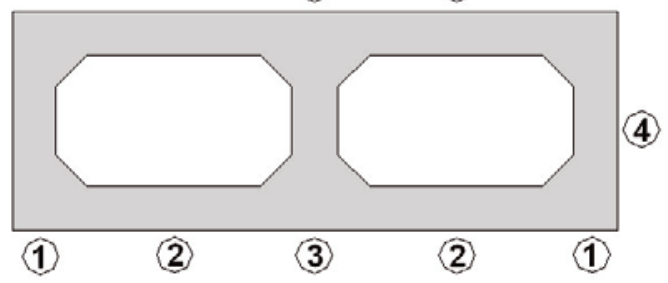

(a)

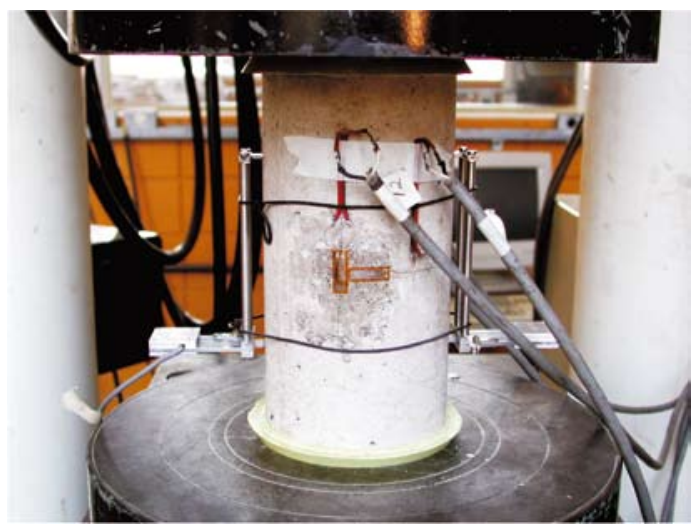

(b)
The test load was applied through a $25 \mathrm{~mm}$ thick rectangular steel platen (394 mm x $194 \mathrm{~mm}$ ). On the top, this platen was connected to the loading system by means of a $294 \mathrm{~mm}$ diameter rigid steel cylinder. On the bottom, the test samples were supported by the rigid steel block of the Universal testing machine. The dimensions of the platen fulfil the recommendations of Atkinson [14] and the Brazilian Code NBR 7184 [15]. Figure 3 illustrates the test set-up. Concrete that constitutes the core blocks was characterized by compression and tension tests of cylindrical concrete samples $(100 \times 200 \mathrm{~mm})$.

Eight displacement transducers (base length $=100 \mathrm{~mm}$ ) were positioned along vertical reference lines on the blocks to measure average strain. The localization of measurement lines is shown in Figure 4. The front view of displacement transducers is represent- ed in Figure 3b. For example, reference line 2 locates a transducer that is disposed on the main face of the block, in the middle of the hollow. The strain measurement in cylindrical concrete samples was performed by two displacement transducers.

Compression and tension tests of blocks are illustrated in Figure 5. During the compression tests of blocks, cracks appeared at a load level about $80 \%$ of the ultimate load, in a diagonal direction along the larger face of the blocks. These cracks showed to be of crushing type and were succeeded by progressive spalling. Internally to the block, critical cracks proceeded along an inclined plane, towards the transversal webs.

The failure mode of the blocks can be characterized as combined compression-shear failure (Figures $6 a$ and Figure $6 \mathrm{~b}$ ). This failure occurred due to the low height-to-width ratio of the block that re-

\section{Figure 5 - Displacement transducers in block compression test (a). Block submitted to indirect tension test (b)}

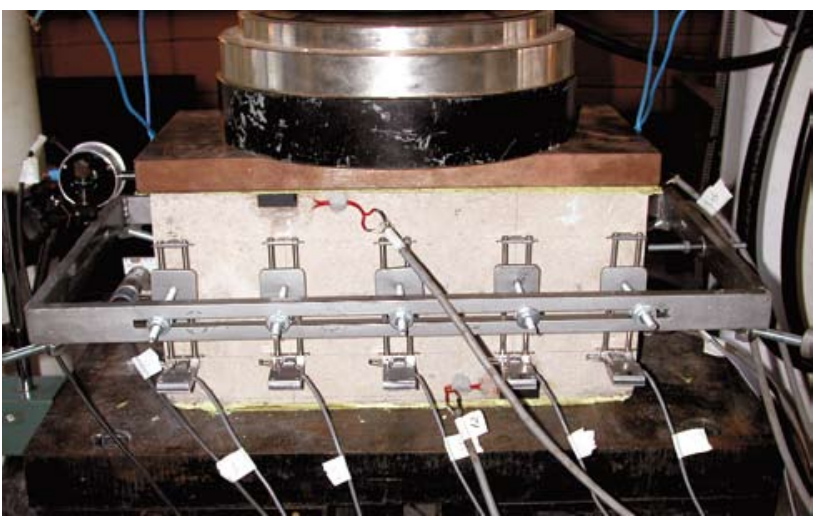

(a)

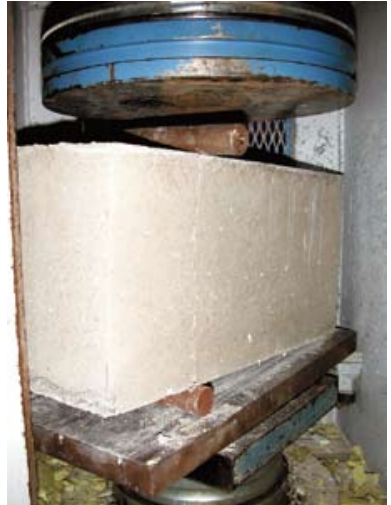

(b) 
Figure 6 - Failure of hollow concrete blocks with inclined cracks and spalling of face-shells (a) and web (b). Failure in indirect tension test (c)

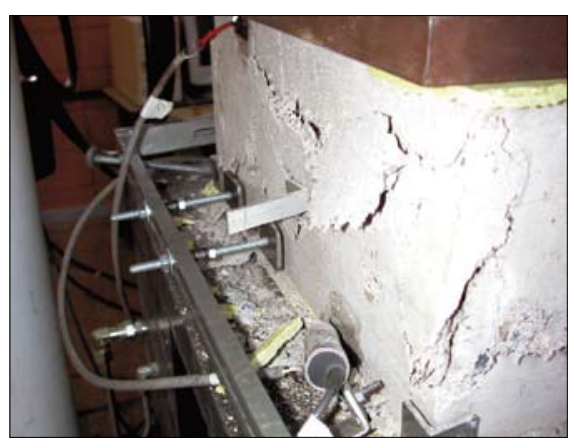

(a)

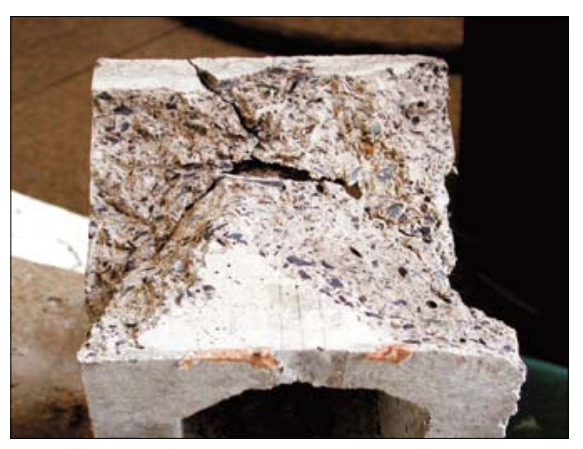

(b)

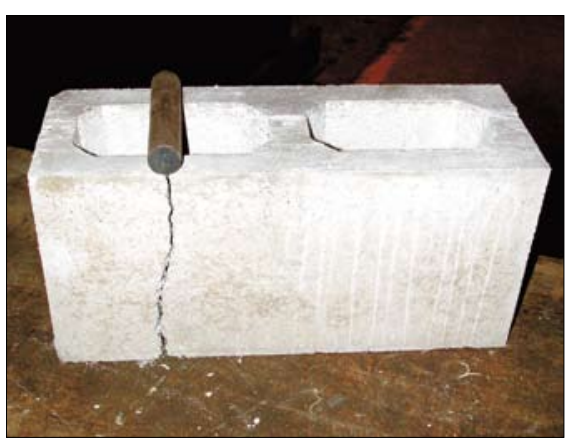

(c) sults in a significant confinement effect derived from the machine platen restraint. Figure $6 \mathrm{c}$ illustrates the vertical crack that arose at the larger face of a block in an indirect tension test.

The correlations of the compressive strength of samples and blocks obtained in the experimental program are sometimes distinct than

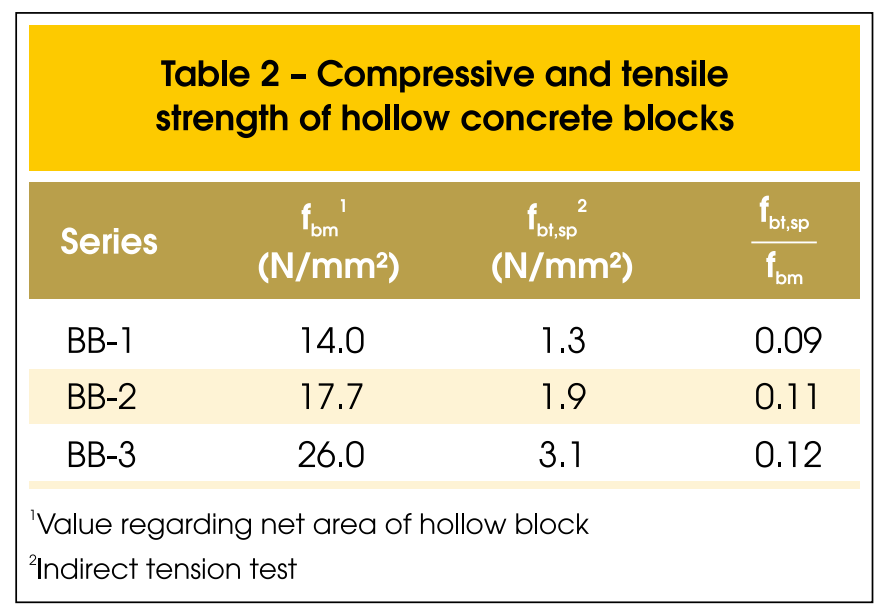

\section{Table 3 - Compressive strength of cylindrical concrete samples and blocks}

\begin{tabular}{|cccc|} 
Series & $\begin{array}{c}\mathrm{f}_{\mathrm{cm}} \\
\left(\mathrm{N} / \mathrm{mm}^{2}\right)\end{array}$ & $\begin{array}{c}\mathrm{f}_{\mathrm{bm}} \\
\left(\mathrm{N} / \mathrm{mm}^{2}\right)\end{array}$ & $\begin{array}{c}\mathrm{f}_{\mathrm{bm}} \\
\mathrm{f}_{\mathrm{cm}}\end{array}$ \\
B-1 & 14.1 & 14.0 & 0.99 \\
& 15.4 & 12.6 & 0.82 \\
B-2 & 18.0 & 16.5 & 0.92 \\
& 20.6 & 17.7 & 0.86 \\
B-3 & 30.9 & 26.0 & 0.84 \\
& 35.9 & 24.4 & 0.68 \\
\hline
\end{tabular}

those presented in Table 1. The differences are due mainly to distinct tests set-ups, the different type of units (solid or hollow blocks) and to differences in size of blocks and samples.

\section{Analysis of the test results}

The preliminary set of tests indicates a small value of coefficient of determination, always less than $5 \%$. For this reason it was defined for each group of test, the quantity of six samples and three blocks for compression and tension test. The values presented in the tables refer to the mean value and coefficient of variation of each group.

Table 2 summarizes the compressive and tensile strength of the hollow concrete block tests. It can be seen that the tensile strength is about $10 \%$ of the compressive strength. These tests (referred by letter BB in the followed tables) were carried out to evaluate the compressive and tensile strength of blocks and samples. The elements were tested without monitoring displacements, and correlations between the mechanical properties of blocks and samples have been established.

An additional set of tests (named B in the followed tables) with displacement transducers (Figure 3 and Figure 4) was carried out to obtain the stress-strain relationships of the elements. Tables 3 and 4 present the relationships between compressive and tensile strength of blocks and samples. These relationships can also be

\begin{tabular}{|cccc|}
\hline \multicolumn{4}{|c|}{$\begin{array}{c}\text { Table 4 - Tensile strength of cylindrical } \\
\text { concrete samples and blocks }\end{array}$} \\
Series & $\begin{array}{c}\mathrm{f}_{\mathrm{ctss}} \\
\left(\mathrm{N} / \mathrm{mm}^{2}\right)\end{array}$ & $\begin{array}{c}\mathrm{f}_{\mathrm{btsp}} \\
\left(\mathrm{N} / \mathrm{mm}^{2}\right)\end{array}$ & $\begin{array}{c}\mathrm{f}_{\mathrm{btsp}} \\
\mathrm{f}_{\mathrm{ctsp}}\end{array}$ \\
\hline B-1 & 1.9 & 1.3 & 0.68 \\
B-2 & 2.2 & 1.9 & 0.86 \\
B-3 & 2.7 & 3.1 & 1.15 \\
& 3.1 & 3.4 & 1.10 \\
\hline
\end{tabular}




\section{Table 5 - Mechanical properties of 100x 200 mm cylindrical samples}

\begin{tabular}{|c|c|c|c|}
\hline Series & $\begin{array}{c}\text { Average } \\
\text { compressive } \\
\text { strength } \\
\mathrm{f}_{\mathrm{cm}}\left(\mathrm{N} / \mathrm{mm}^{2}\right)\end{array}$ & $\begin{array}{l}\text { Strain at } \\
\text { failure } \\
(\mu)\end{array}$ & $\begin{array}{l}\text { Modulus of } \\
\text { Elasticity } \\
E_{c}\left(\mathrm{~N} / \mathrm{mm}^{2}\right)\end{array}$ \\
\hline B-1 & $17.3\left(4,3 \%^{1}\right)$ & 2910 & 16199 \\
\hline B-2 & $20.4\left(1,8 \%{ }^{1}\right)$ & 2707 & 19407 \\
\hline B-3 & $41.5\left(4,0 \%{ }^{1}\right)$ & 3061 & 25484 \\
\hline
\end{tabular}

observed in the graphs shown in Figure 7. Figure 8a illustrates the stress-strain curves of the samples.

Values of mechanical properties obtained in sample tests are presented in Table 5. The Poisson ratio value obtained for all strength levels is about 0.19 . In Figure $8 \mathrm{~b}$ it can be seen graphs of stress versus longitudinal and transversal strain for concrete samples, obtained from B-1 group of tests.

Table 6 summarizes the mechanical properties obtained from compression tests of hollow blocks.

Compressive and tensile strength values of blocks and cylindrical samples are correlated according to the distribution shown in Figure 9. Two curves represent the distribution of the data of Figure 9a - a linear curve and an exponential curve -, which present almost the same coefficient of determination, 0,985 and 0,986 , respective- ly. Equations 1 and 2, valid for sample compressive strength range from $10 \mathrm{~N} / \mathrm{mm}^{2}$ to $45 \mathrm{~N} / \mathrm{mm}^{2}$, define the correlation curves.

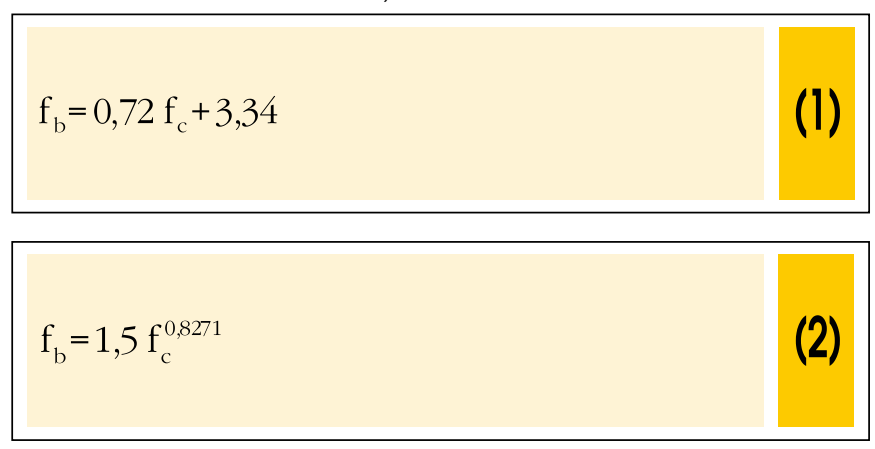

Figure 10 presents two kinds of curves for each block test series. The first is a stress versus strain graph that shows the evolution of stress and strain at points 1 to 4 of the blocks. The second shows the presumed strain variation along block faces, referring to five levels of loading. The loading levels are associated to the maximum stress $\sigma_{\mathrm{u}}$ reached in tests. For both kinds of curves, the strain obtained is the average of all displacement transducers values of each reference line (see Figure 4).

Due to block geometry, measured strain throughout face-shells and webs presents different values. Points 1 and 4 are subjected to lower deformations while points 2 and 3 present a similar higher level of deformation. This behaviour can be justified considering that point 1 is part of the outer transversal web and point 4 is close to the face-shells. Otherwise, point 2 presents higher strain values and this influences the behaviour of point 3 . It can be observed from Figure 10 that strain values at points 2 and 3 show, for $40 \%$ of the peak stress, values near 7 times the strain values at points

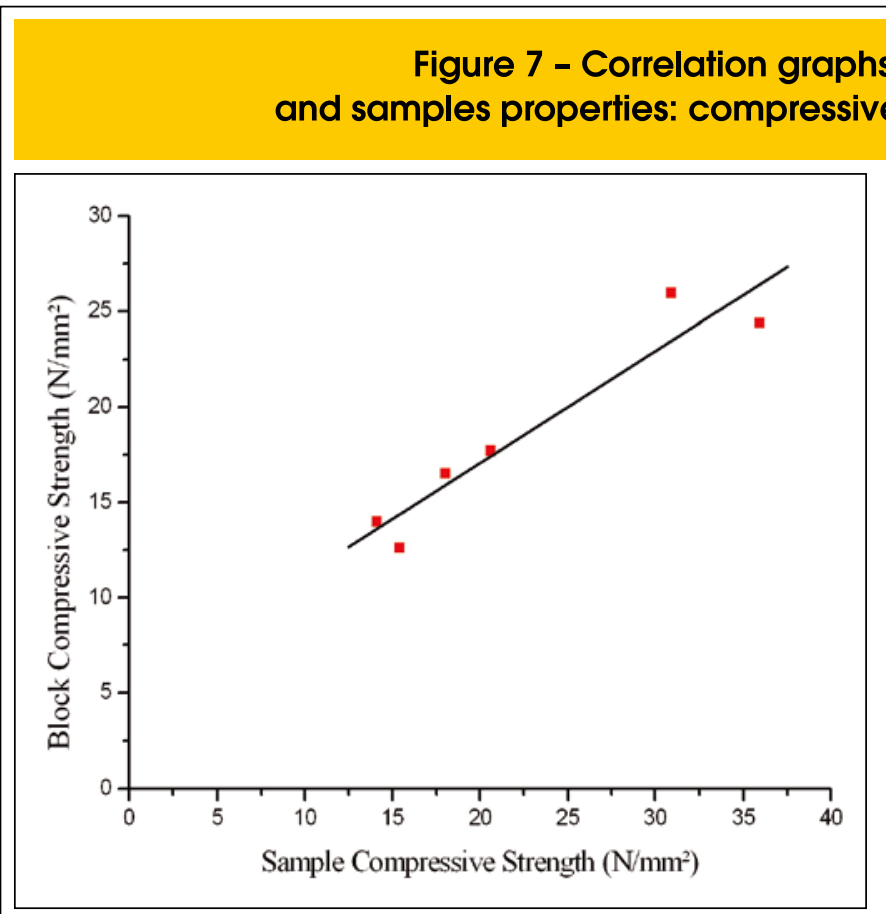

(a)

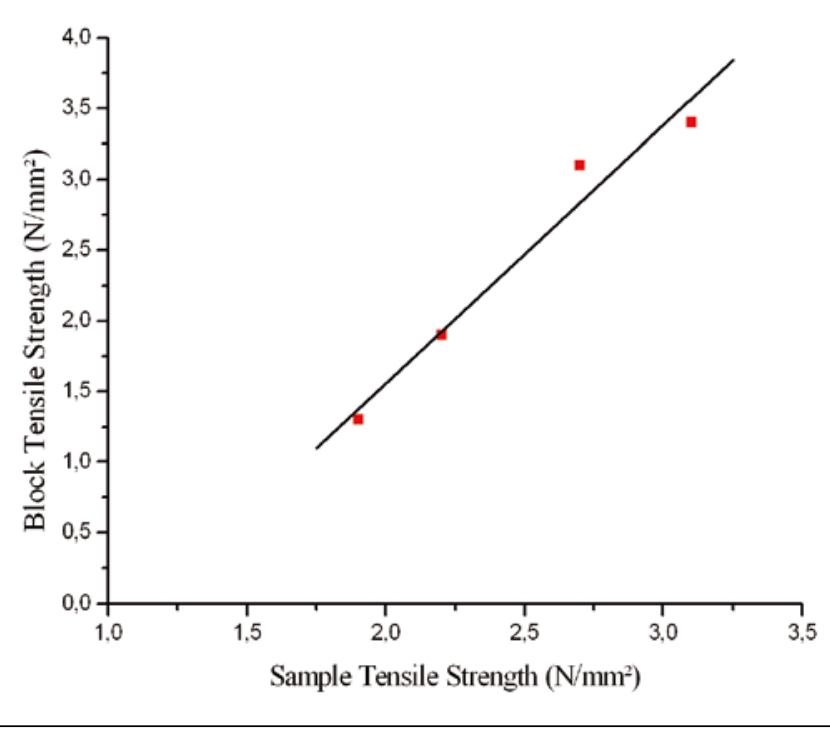

(b) 
Figure 8 - Stress-strain curves for: concrete blocks (a) and cylindrical concrete samples (b)

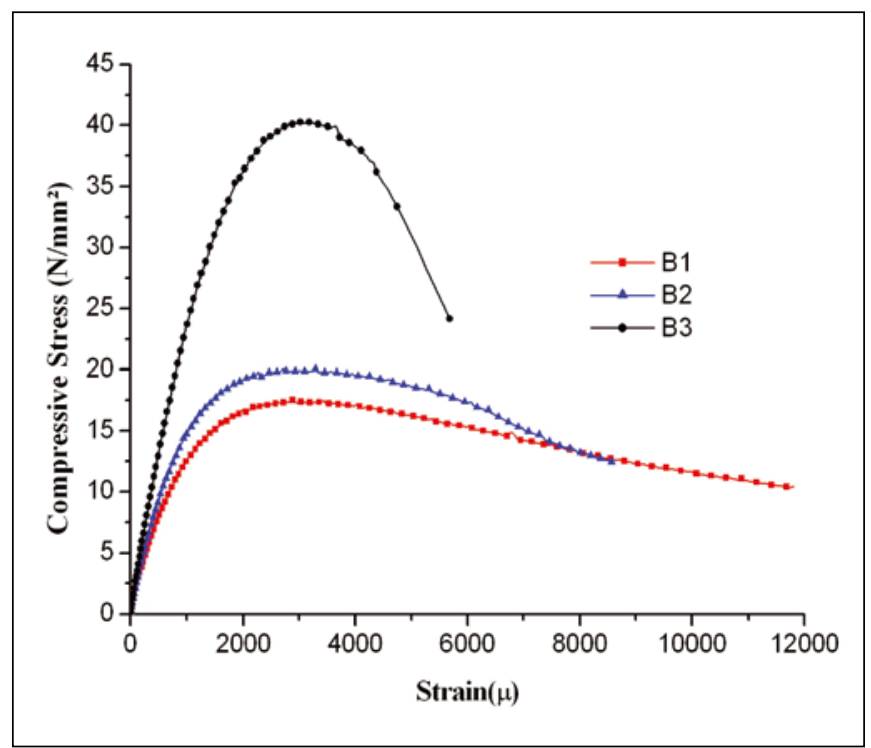

(a)

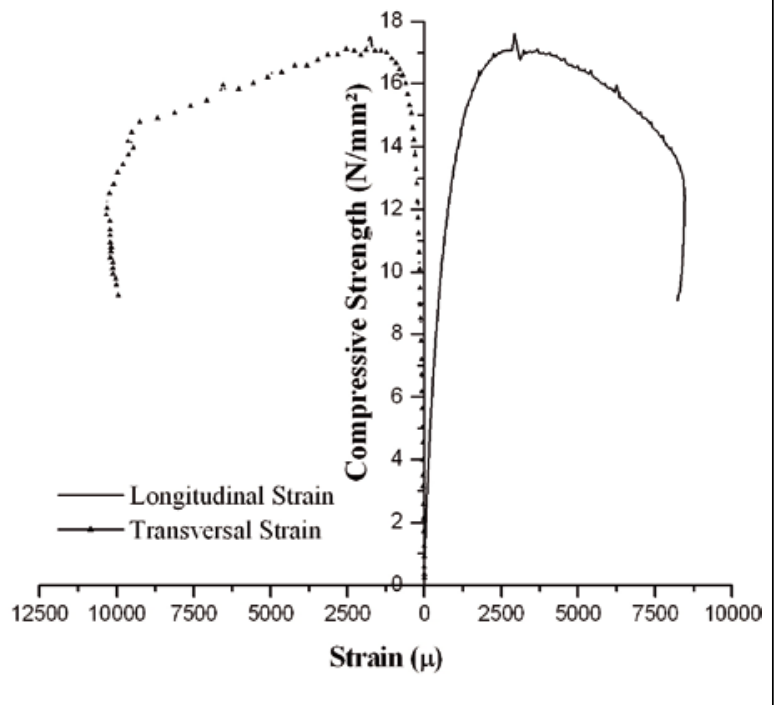

(b)

Table 6 - Compressive strength and strain value obtained in block tests

\begin{tabular}{|c|c|c|c|c|}
\hline \multirow{2}{*}{ Series } & \multirow{2}{*}{$\begin{array}{c}\text { Average } \\
\text { compressive } \\
\text { strength' } \\
\mathrm{fb}_{\mathrm{m}} \\
\left(\mathrm{N} / \mathrm{mm}^{2}\right)\end{array}$} & \multirow{2}{*}{$\begin{array}{l}\text { Instrument } \\
\text { Points }\end{array}$} & \multicolumn{2}{|c|}{ Strain $(\mu)$} \\
\hline & & & At peak & At $40 \%$ Peak \\
\hline \multirow{4}{*}{ B-1 } & \multirow{4}{*}{$16.8\left(2,5 \%^{2}\right)$} & 1 & 1840 & 104 \\
\hline & & 2 & 6683 & 821 \\
\hline & & 3 & 7549 & 917 \\
\hline & & 4 & 2136 & 138 \\
\hline \multirow{4}{*}{ B-2 } & \multirow{4}{*}{$19.8\left(4,8 \%^{2}\right)$} & 1 & 1801 & 118 \\
\hline & & 2 & 5889 & 834 \\
\hline & & 3 & 4511 & 1059 \\
\hline & & 4 & 1562 & 219 \\
\hline \multirow{4}{*}{ B-3 } & \multirow{4}{*}{$35.7\left(3,9 \%^{2}\right)$} & 1 & 1408 & 173 \\
\hline & & 2 & 4227 & 1094 \\
\hline & & 3 & 3052 & 919 \\
\hline & & 4 & 340 & 187 \\
\hline
\end{tabular}




\section{Figure 9 - Relationship between compressive strength of blocks and cylindrical samples}

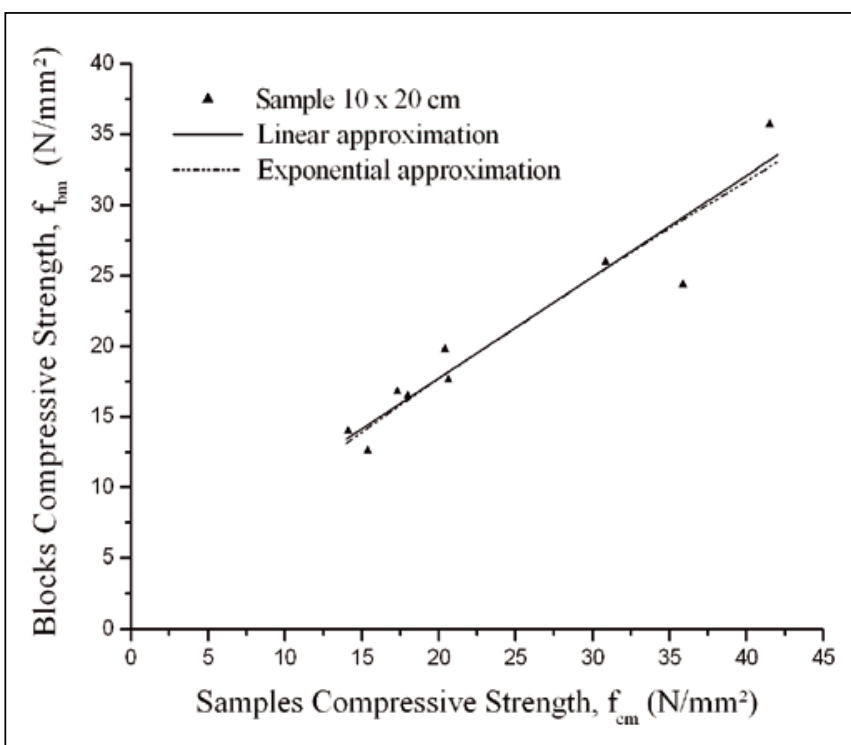

(a)

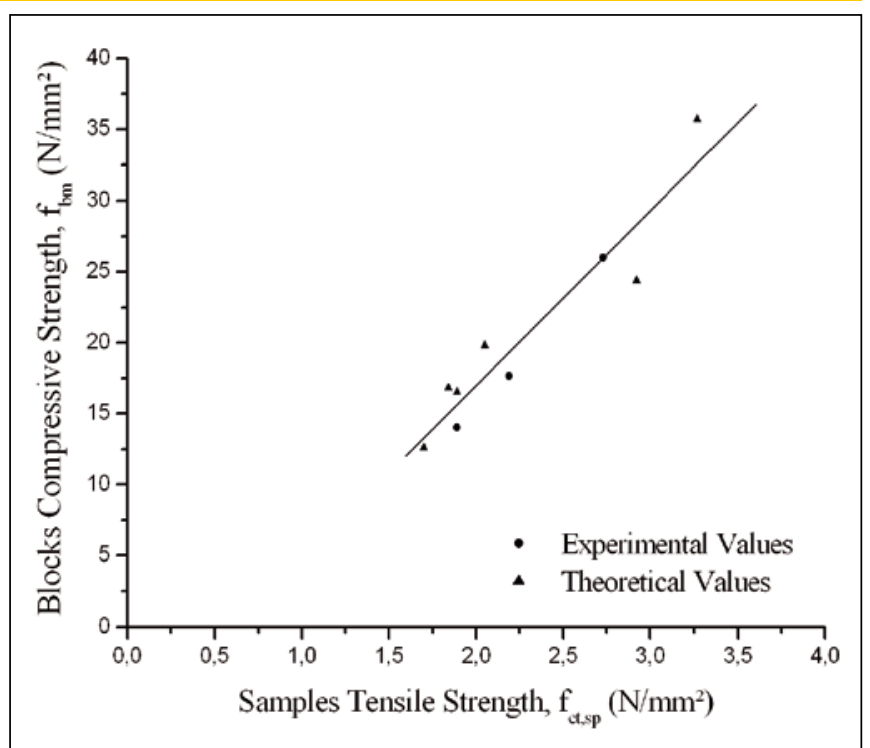

(b)
1 and 4 . The comparison of these values indicates that a non-uniform stress distribution occurs due to confinement effect.

It can be seen in the stress-strain graphs that the initial slope of curves 2 and 3 is significantly different from the initial slope of curves 1 and 4 , the latest showing a stiffer behavior. In addition, a distinct behaviour can be observed in the softening branch, which curves 1 and 4 showing a steeper descending branch, hence a more brittle behavior.

Considering strain variation lines, it can be seen that at $20 \% \sigma_{u}$ the strain values at points 1 and 4 are almost insignificant, while strain value at point 3 is close to the one at point 2 strain, slightly higher. Increasing the loading level, strain values increase, mainly in the middle of the block. At $60 \%$ of $\sigma_{u}$, the difference of strain between middle and outer points is higher than at initial stress levels. From about $60 \% \sigma_{u}$, an inverted behaviour occurs and point 2 presents higher strain than point 3 . Starting from $80 \% \sigma_{u}$, strain distribution is strongly influenced by cracking of concrete. The strain variation lines were depicted considering the symmetry condition starting from average values obtained for each reference line.

Block geometry and confinement effect are determinant factors of the stress distribution throughout face-shells and webs of block. In the particular tests, however, an unexpected distortion was introduced by the rigidity of the steel platen. Despite of the fulfilment of recommended platen thickness, a slight non-uniform displacement of the top of the block was observed. This means that the used steel platen between the block top surface and the loading system was not able to transmit a perfectly uniform pressure. This behavior was observed by means of linear numerical analysis that indicates the displacements of plate edges are smaller than obtained in middle points (see more detail in Barbosa [13]). Even so, the obtained test results showed to be compatible with those presented by Becica and Harris [9].

\section{Theoretical analysis}

A peculiar method of analysis was applied to evaluate strength and deformability of the tested concrete blocks, also to verify the consistency of the stress and strain values obtained experimentally. A link between mechanical properties of concrete cylindrical samples and block is established to preview the load capacity of a hollow block.

\subsection{Estimation of the load capacity of the block}

At first, the block transversal section is divided into several regions, named A, B, C and D (Figure 11). From the experimental analysis, an average strain value, for a given load level, is attributed to each kind of region. From the stress-strain curves for cylindrical concrete samples, a corresponding stress value is associated to the strain value. Multiplying this stress value by the area of each region A, B, $C$ and $D$, values of resisting forces can be obtained. The estimated resistant force $\left(\mathrm{F}_{\text {resist }}\right)$ is obtained by summing the resisting forces on the several areas. A comparison of estimated and measured (from the load-cell reading) load capacities is presented in Table 7 , where five load levels were considered.

It can be seen in Table 7 that on the initial load levels, there are substantial differences among estimated and measured load values. However, on higher loading levels, these differences diminish. At the two highest levels, the difference is smaller than $10 \%$ and the ultimate load estimated values are always smaller than the measured ones.

The estimation method is empirical and it does not consider any correction or weighting factor. The most interesting result of this kind of analysis is that the equilibrium conditions had been sat- 
Figure 10 - Stress-strain graphs and strain variation along the main face and webs of hollow concrete blocks: (a,b) Series B-1; (c,d) Series B-2; and (e,f) Series B-3

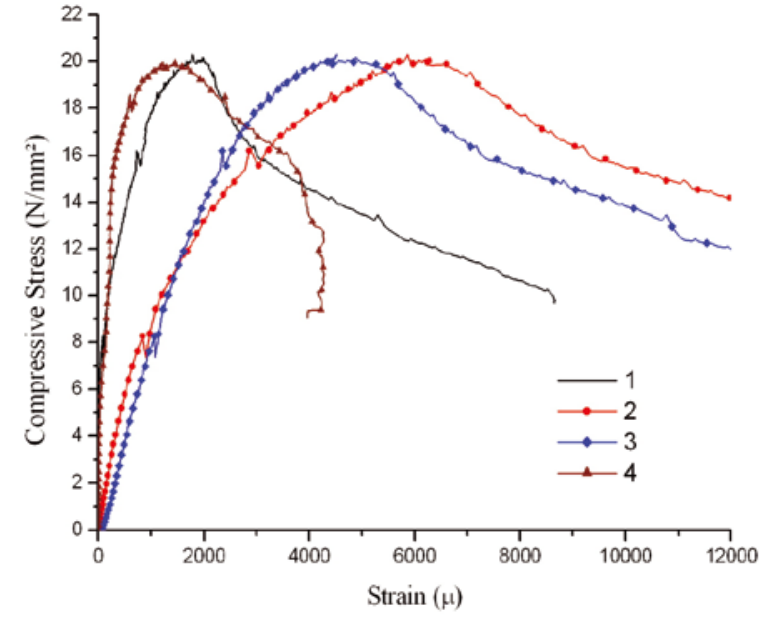

(a)

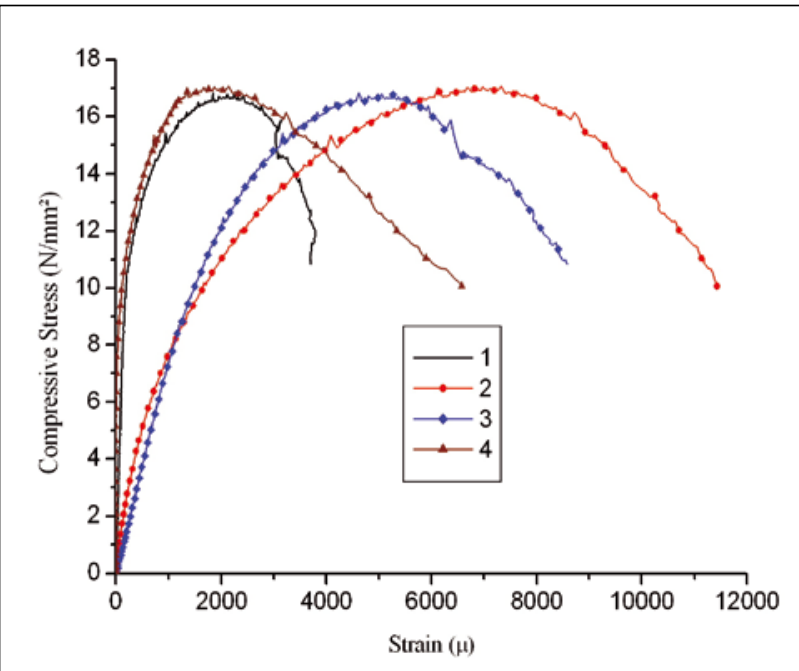

(c)

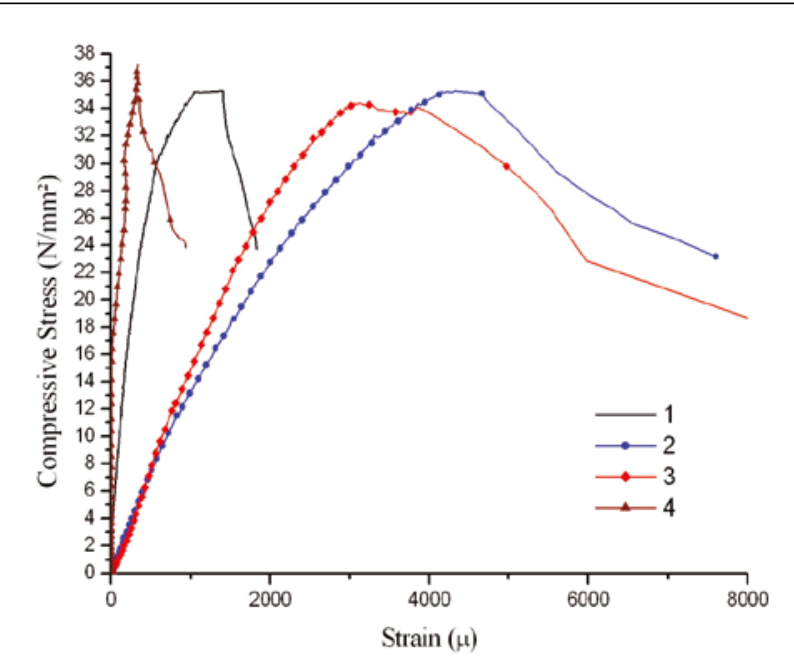

(e)

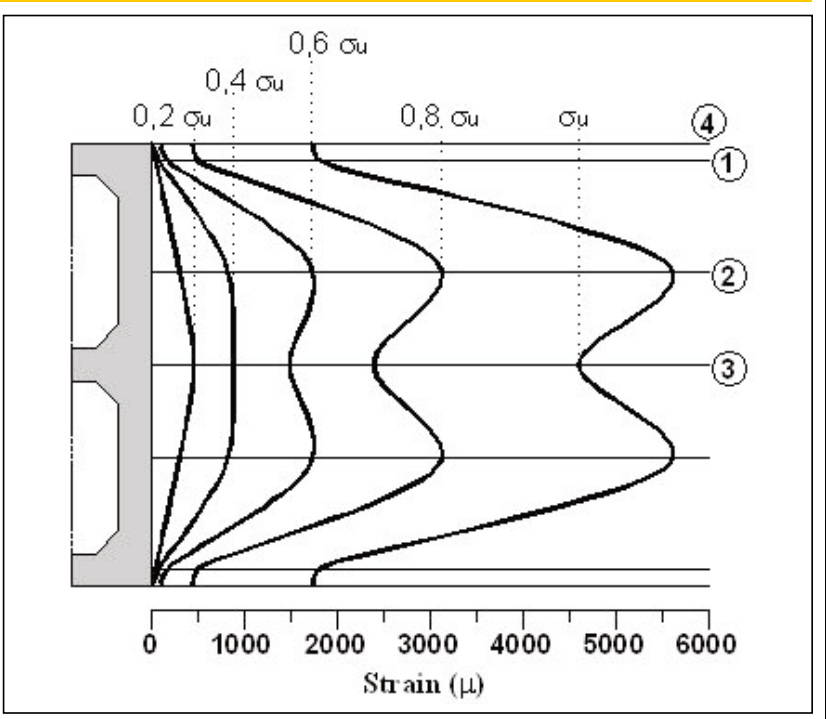

(b)

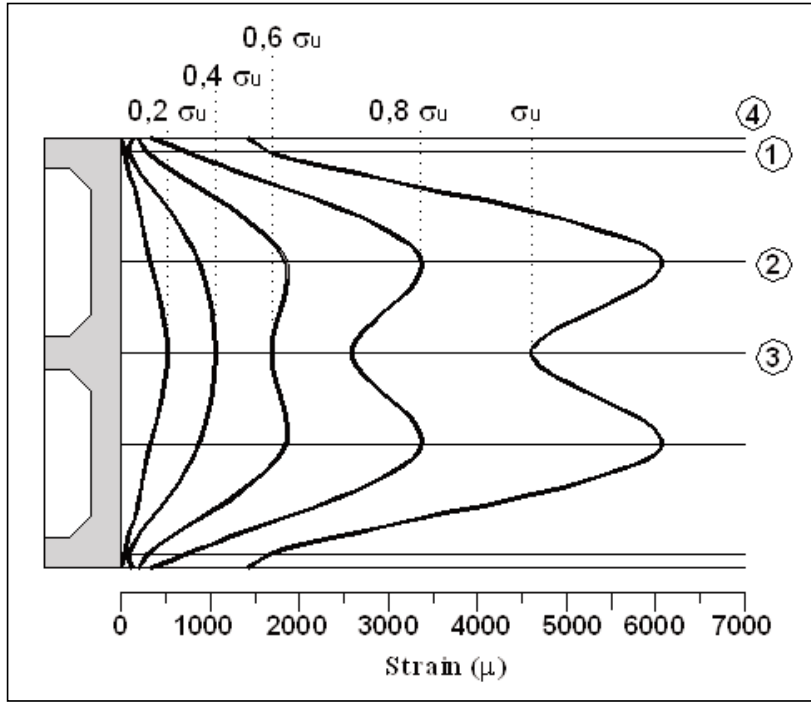

(d)

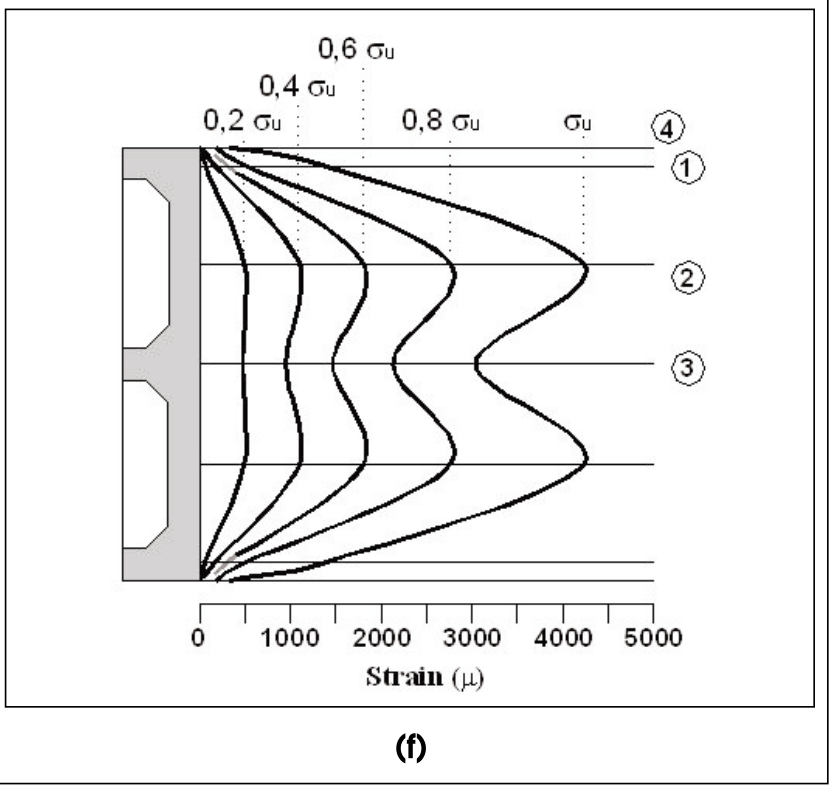




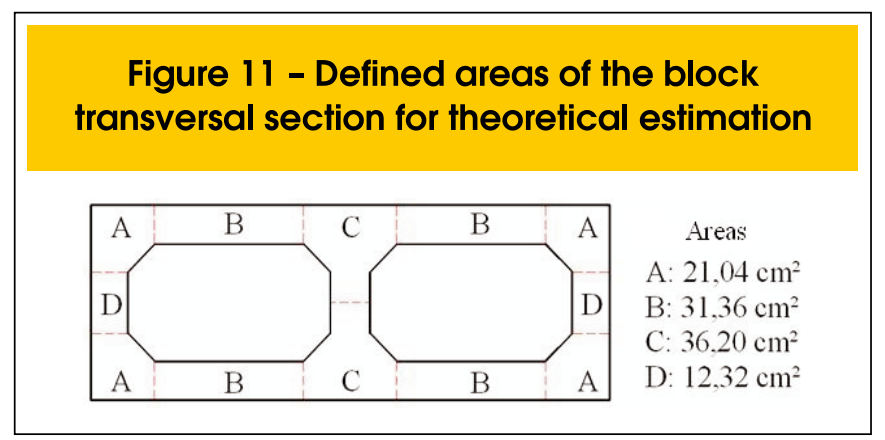

isfactorily verified from the strain distribution on the blocks and the stress-strain curves of the cylindrical concrete samples. This means that if a strain field can be found and the stress-strain curves are available, than a good estimation of the block load capacity can be obtained. Especially, this analysis can be performed for different levels.

In this way, Figure 12 shows theoretical curves obtained from the estimation of resisting forces on several loading levels. In Figure 12 , the curve obtained from the average of measure displacements at all points is close to the corresponding theoretical curve. The comparison shows a reasonable agreement, despite of the simplifications in the empirical procedure. One major simplification was that the average strain experimental value was extended to the entire block height, thus neglecting the actual strain variation along height.

In the same Figure 12, another curve considers only the most deformable points in the block, located in the centre of the faceshells. From this curve, the lowest stiffness of the block is obtained. Therefore, this analysis overestimates the block's deformability. By multiplying the stress obtained from the sample test by the block net area and then extending the average strain to the entire block height, the force-displacement curve of the sample can be traced. This curve shows stiffness close to the one obtained theoretically, by considering strain values in all block points.

In structural safety analysis there are safety factors $\left(\gamma_{\mathrm{w}}\right)$ that consider, for instance, differences between the compressive strength obtained on cylindrical sample tests and the value that will probably be found in actual structures.

In a similar way, safety factors - either pre-established values or factor derived from parametric analyses - can be applied to experimental results. For example, there are known correlations factor that consider scale effects on cylindrical concrete sample tests. In relation to block tests, the number of variables increases and no single correlation can be established by modifying coefficients or single adjustment.

\section{Table 7 - Resistant force of block associated to five levels of load}

\begin{tabular}{|c|c|c|c|c|}
\hline Series & Level of force & $\begin{array}{l}\mathrm{F}_{\text {machl }} \\
(\mathrm{kN})\end{array}$ & $\begin{array}{l}\mathrm{F}_{\mathrm{b}, \text { esist }} \\
(\mathrm{kN})\end{array}$ & $\frac{F_{\mathrm{b}, \text { resist }}}{F_{\text {mach }}}$ \\
\hline \multirow{5}{*}{ B-1 } & $0.2 F_{\max }$ & 103.7 & 140.5 & 1.36 \\
\hline & $0.4 F_{\max }$ & 206.6 & 265.9 & 1.29 \\
\hline & $0.6 F_{\max }$ & 309.8 & 348.1 & 1.12 \\
\hline & $0.8 F_{\text {max }}$ & 413.1 & 421.3 & 1.02 \\
\hline & $\mathrm{F}_{\text {max }}$ & 516.3 & 505.2 & 0.98 \\
\hline \multirow{5}{*}{ B-2 } & $0.2 F_{\max }$ & 124.5 & 169.7 & 1.36 \\
\hline & $0.4 \mathrm{~F}_{\max }$ & 249.0 & 331.7 & 1.33 \\
\hline & $0.6 F_{\max }$ & 373.5 & 442.0 & 1.18 \\
\hline & $0.8 F_{\max }$ & 498.0 & 528.6 & 1.06 \\
\hline & $\mathrm{F}_{\max }$ & 622.5 & 558.9 & 0.90 \\
\hline \multirow{5}{*}{ B-3 } & $0.2 F_{\max }$ & 216.4 & 279.9 & 1.29 \\
\hline & $0.4 F_{\max }$ & 432.8 & 573.1 & 1.23 \\
\hline & $0.6 F_{\max }$ & 649.2 & 749.3 & 1.15 \\
\hline & $0.8 F_{\max }$ & 865.6 & 922.3 & 1.07 \\
\hline & $F_{\max }$ & 1082.0 & 1033.3 & 0.96 \\
\hline
\end{tabular}




\subsection{Deformability of block}

The block deformability is estimated from the mechanical properties of cylindrical concrete samples. The exponential approximation represented by Equation 2 is used to correlate concrete sample strength to block strength.

The slope of the line that joins the strain value $50 \mu$ to the strain corresponding to $40 \%$ of the compressive strength point is named the fictitious elasticity modulus $\left(\mathrm{E}_{\mathrm{b}, \mathrm{fic}}\right)$ of the block.

For each point (points 1 to 4 , Figure 4 a) that corresponds to a region,

$$
\mathrm{E}_{\mathrm{b}, \mathrm{fic}}=0,73 \mathrm{E}_{\mathrm{c}}-4648
$$

there is a corresponding average $\mathrm{E}_{\mathrm{b} \text {,fic }}$. Table 8 presents a particular association, where $\mathrm{E}_{\mathrm{b} f \mathrm{fic}}$ represents the average value between points 2 and 3 . Figure 13 illustrates the correlation between $\mathrm{E}_{\mathrm{b} \text { fic }}$ and $\mathrm{E}_{\mathrm{c}}$ and two approximation curves. In this case, the analyses

\section{Figure 12 - Experimental and theoretical force-displacement curves. (a) Series B-1; (b) Series B-2; (c) Series B-3}

(a)

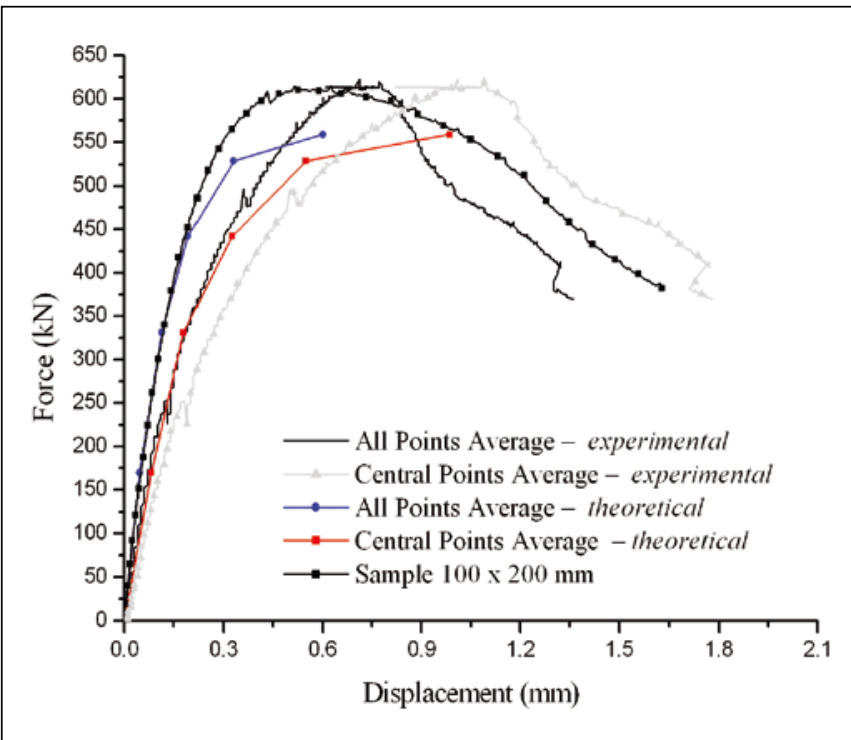

(b)

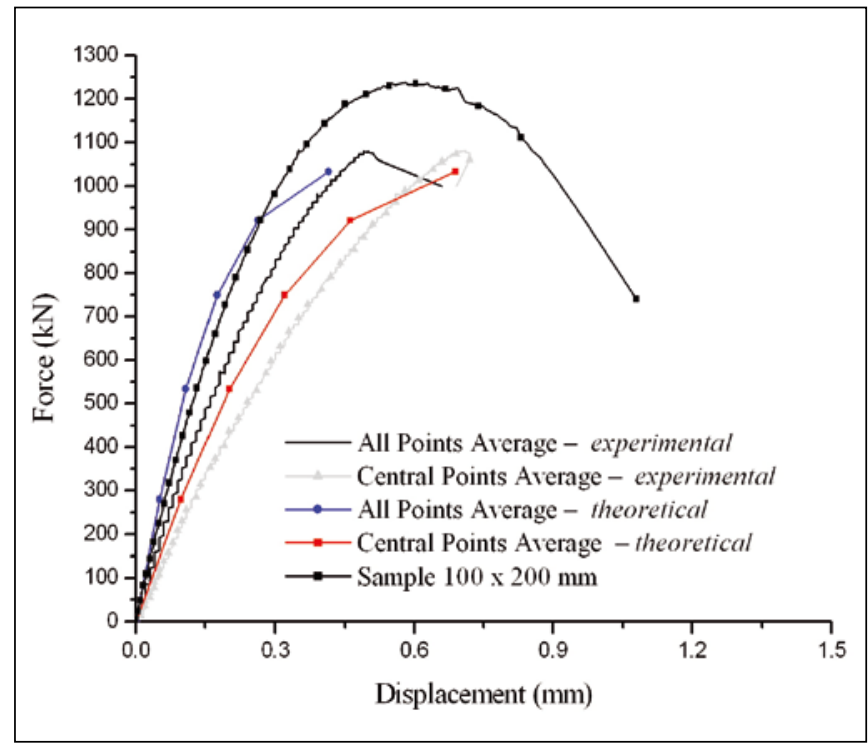

(c) 
Figure 13 - Correlation between elasticity modulus of concrete and fictitious elasticity modulus of block - referred to central points

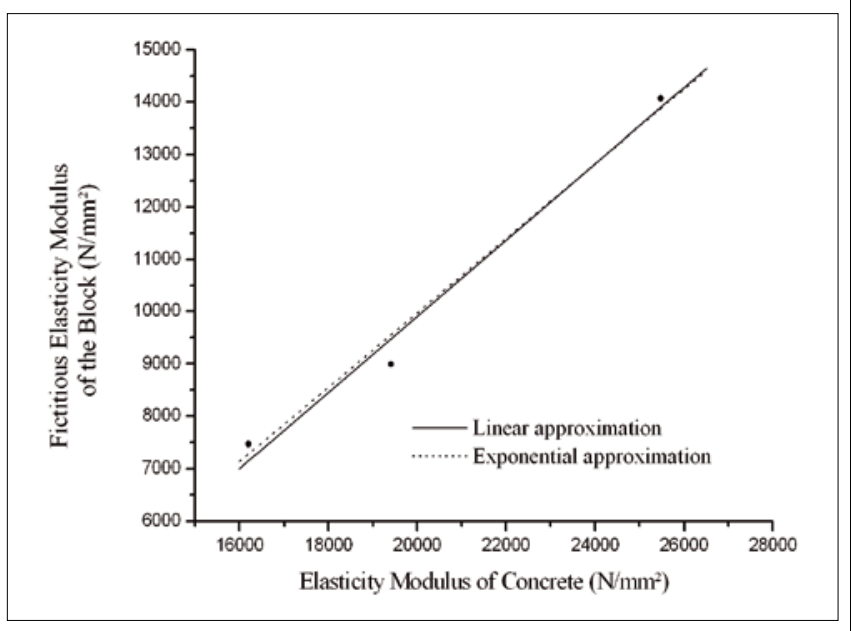

Table 8 - Elasticity modulus of cylindrical concrete samples and concrete blocks

\begin{tabular}{|ccc|}
\hline Series & $\mathrm{E}_{\mathrm{b}_{\mathrm{b}, \mathrm{fic}}}{ }^{1}(\mathrm{MPa})$ & $\mathrm{E}_{\mathrm{c}}(\mathrm{MPa})$ \\
$\mathrm{B}-1$ & 7462 & 16199 \\
$\mathrm{~B}-2$ & 8991 & 19407 \\
B-3 & 14070 & 25484 \\
'Related to average values of points 2 and 3, near the \\
block center.
\end{tabular}

lead to linear approximation represented in Equation 3. The constant in Equation 3 is associated to differences of strains measured in sample and block tests due to distinct confinement effect.

A tentative estimation of the block deformability can be done as follows:

- mechanical properties of blocks $\left(\mathrm{f}_{\mathrm{b}} \mathrm{e} \mathrm{E}_{\mathrm{b}, \mathrm{fic}}\right.$ ) are determined using equations 2 and 3 , starting from mechanical properties of cylindrical concrete samples;

strain in blocks and concrete samples at $40 \%$ maximum stress are measured for each element, assuming $\sigma=\mathrm{E} \varepsilon$;

stress-strain relationships are defined for each case and an adjustment coefficient $(\alpha)$ is attributed between the two curves. The coefficient is defined as the relationship between two straight lines;

- concrete sample stress-strain curves are defined and the concrete compressive strength is adjusted according to the block compressive strength, by Equation 3, and their strains by $\alpha$ coefficient.

For example, for B-2 group $\mathrm{f}_{c}=20,4 \mathrm{MPa}$ and by means of Equation (2) it is estimated $\mathrm{f}_{\mathrm{b}}=18,2 \mathrm{MPa}$. From Equation 3 and $\mathrm{E}=19407 \mathrm{MPa}$, it is obtained $\mathrm{E}_{\mathrm{b}, \mathrm{ap}}=9478 \mathrm{MPa}$. The value of $\alpha$ coefficient for this example is $\mathrm{E} / \mathrm{E}_{\mathrm{b}, \mathrm{ap}}=2,04$.

Thus, it is possible to obtain the block stress-strain curve from concrete mechanical properties acquired in cylindrical concrete sample compression tests. Table 9 presents a summary of this procedure. Figure 14 shows a block stress-strain curve obtained from the mechanical properties of concrete samples, as well as a block stress-strain curve obtained experimentally. Despite the fact that theoretical parameters were obtained from experimental results in the linear-elastic range - what is supposed to lead to good correlations-, a unique equation of correlation (Equation (3)) for all groups was utilized.

The proposed analysis gives a reasonable indication of the deformation behaviour of the block. At lower stress levels the estimated curve become closer to the experimental one and the correlation of compressive strength determines the most differences among the relationships.

However, theoretical curves always present compressive strength values lower than those obtained experimentally. It is possible that if a very rigid steel platen is used in the test set-up, a better approximation can be obtained.

\section{Conclusions}

Several researches aim to correlate mechanical properties of hollow concrete blocks and mechanical properties of concrete that constitute it. They are limited to single comparisons between compressive strength values obtained in tests of blocks and concrete samples. The results of this kind of study cannot be extended to all situations because many variables influence them, such as geometry of blocks and concrete samples, confinement effects, moulding or extraction methods and variability of test results.

This paper presented some preliminary results of a broader research that targets a detailed analysis of structural behaviour of blocks, prisms and masonry walls. The reported results are par-

Table 9 - Parameters applied to block theoretical stress-strain curve

\begin{tabular}{|cccccccc|}
\hline Series & $f_{c}$ & $f_{b}$ & $E_{c}$ & $E_{b}$ & $\varepsilon_{0,4 \text { c }}$ & $\varepsilon_{0,410}$ & $\alpha$ \\
\hline B-1 & 16.8 & 15.4 & 16199 & 7143 & 415 & 865 & 2.27 \\
B-2 & 20.4 & 18.1 & 19407 & 9478 & 421 & 765 & 2.04 \\
B-3 & 41.5 & 32.6 & 25484 & 13902 & 651 & 939 & 1.83 \\
\hline
\end{tabular}


ticular to the adopted test method, to the block geometry and the compressive strength levels.

Correlations between the compressive strength of blocks and cylindrical samples were obtained with small coefficient of determination $(0,81)$. The block geometry influences the strain distribution and respective stresses. Test conditions, especially the steel platen rigidity, can affect the strain distribution and consequently the load capacity and deformation behaviour of the block.

An empirical method for estimation of resisting forces was applied. Equilibrium conditions had been satisfactorily verified from strain distribution on blocks and stress-strain curves of cylindrical concrete samples. This means that if a strain field can be found and a stress-strain graph is available, than a good estimation of the block load capacity can be obtained. The theoretical ultimate load values showed to be close to the measured load in the tests. In addition, the analysis indicated that stress-strain curves can be anticipated, concerning to the block central points, starting from mechanical properties of concrete, as measured in cylindrical sample tests. More detailed studies can be developed in this way to reach a confident theoretical method of analysis of blocks, prisms and mason-

\section{Figure 14 - Experimental and theoretical block stress-strain curve. Groups 10 (a), 20 (b) and 30 (c)}

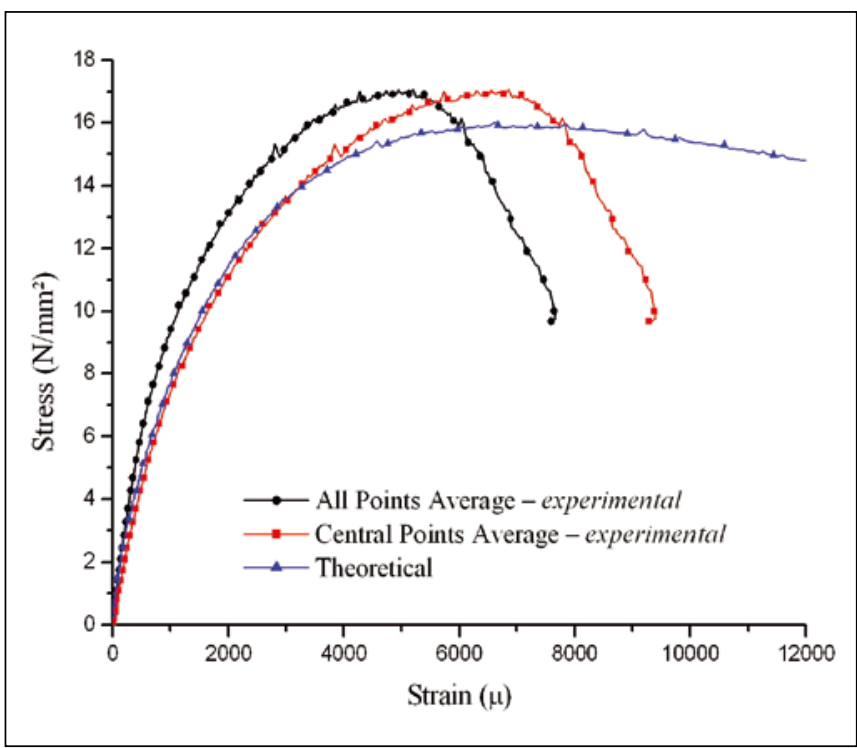

(a)

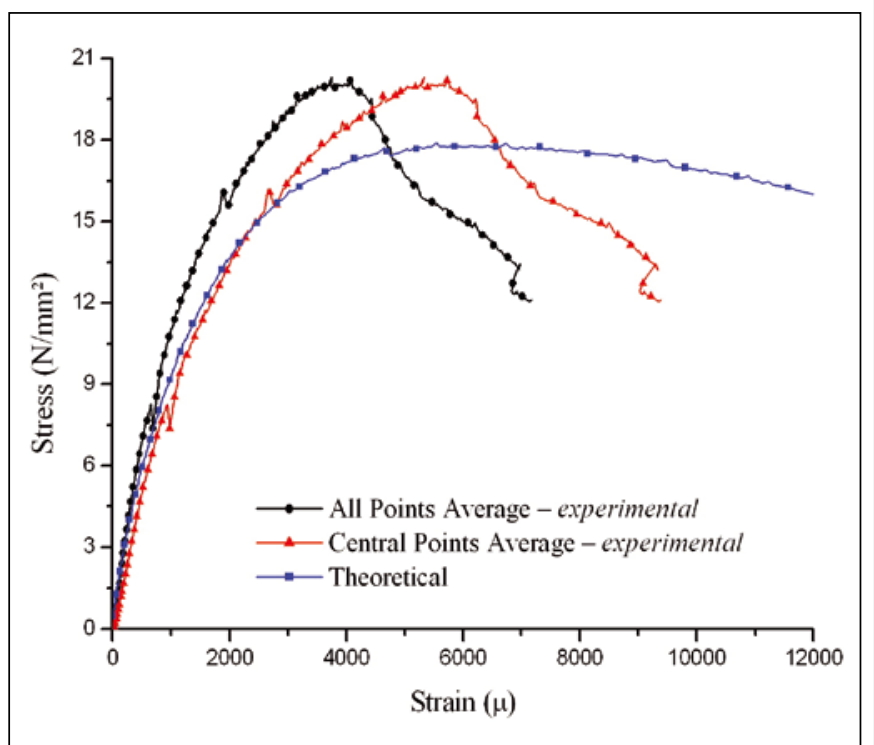

(b)

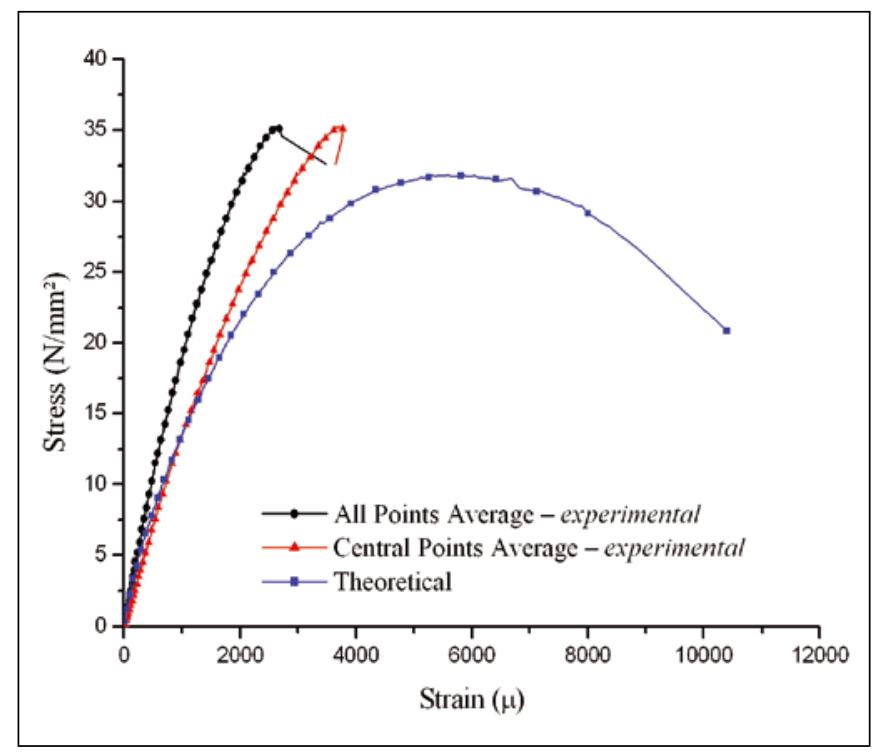

(c) 
ry walls. In addition, a strong perspective arises for the definition of safety and weight factors and algorithms that may better represent the relationships between mechanical properties of the material and the structural behaviour of hollow concrete blocks.

\section{Acknowledgements}

The authors would like to acknowledge FAPESP - Sao Paulo State Research Foundation for the financial support given to this research.

\section{References}

[01] GOMES, I.R.. Numerical simulation of mansonry prisms under compression using Finite Element Methods with interface elements. 160p. PhD Thesis - Federal University of Santa Catarina, Florianópolis, 2001. (in Portuguese).

[02] BERTO, L.; SAETTA, A., SCOTTA, R.; VITALIANI, R.. Failure mechanism of masonry prism loaded in axial compression: computational aspects. Materials and Structures, 38, p.249-56. mar, 2005.

[03] DROBIEC, L. FEM micro model of masonry. In: INTERNATIONAL CONFERENCE AMCM, 5., 2005, Gliwice, Poland. Proceedings.

[04] KÖKSAL H.O., KARAKOÇ C., YILDIRIM H. Compression behavior and failure mechanisms of concrete masonry prisms. Journal of Materials in Civil Engineering, 17(1), pp. 107-15.

[05] HENDRY, A.W. Structural Masonry. 2.ed. Hong Kong: Macmillan Press Ltd, 1998.

[06] MARZAHN, G.A. Extended investigation of mechanical properties of masonry units. In: NORTH AMERICAN MASONRY CONFERENCE, 9., 2003, Clemson, South Carolina. Proceedings. p.813-24, 2003.

[07] PINA-HENRIQUES, J.L. Masonry under Compression: Failure Analysis and Long-Term Effects. 186p. PhD Thesis - University of Minho, Guimaraes, 2005.

[08] HAMID, A.A., CHUKWUNENYE, A.O. Compression behaviour of concrete masonry prisms. Journal of Structural Engineering, 112, (3), p.605-13, mar, 1986.

[09] BECICA, I.J., HARRIS, H.G. Behavior of hollow concrete masonry prisms under axial load and bending. The Masonry Society Journal, 2, (2), p.T1- T26, jan-jun, 1983.

[10] HAWK, S.W., McLEAN, D.I., YOUNG, T.C. Compressive behavior of insulated concrete masonry prisms. The Masonry Society Journal, 15, (2), p.53-60, dec, 1997.

[11] GANZERLI, S. et al. Compression strength testing for nonstandard concrete masonry units. In: NORTH AMERICAN MASONRY CONFERENCE, 9., 2003, Clemson, South Carolina. Proceedings. p.60-71, 2003.

[12] FRASSON JUNIOR, A.F. Methodology for portion and manufacturing process control of concrete blocks for structural masonry. 146p. M.Sc. Thesis - Federal
University of Santa Catarina, Florianopolis, 2000. (in Portuguese)

[13] BARBOSA, C.S. Strength and deformability of concrete hollow blocks and their correlation to mechanical properties of the constituent material. 153p. M.Sc. Thesis - School of Engineering of Sao Carlos, University of Sao Paulo, Sao Carlos, 2004. (in Portuguese).

[14] ATKINSON, R.H. Effect of loading platen thickness on masonry unit and prism strengths. The Masonry Society Journal, Boulder, 10, (1), p.86-94, aug, 1991.

[15] BRAZILIAN ASSOCIATION OF TECHNICAL CODES. NBR 7184: Hollow concrete blocks for masonry Evaluation of compressive strength. Rio de Janeiro, 1982. 